\title{
SOSIALISASI DAN PELATIHAN ALIH MEDIA KABA
}

\author{
Rona Almos, Herry Nur Hidayat, Wasana, Eka \\ Meigalia
}

\begin{abstract}
ABSTRAK
Dalam upaya mengenalkan dan melestarikan karya seni budaya tradisi kaba, perlu adanya sebuah bentuk transformasi kaba tersebut. Salah satu bentuk transfromasi itu adalah perubahan menjadi bentuk komik sehingga diharapkan akan lebih mudah diterima oleh khalayak penikmat terutama remaja dan anak-anak.

Kegiatan ini adalah wujud kelanjutan hasil penelitian terhadap kemungkinan transformasi cerita kaba menjadi cerita anak dan komik. Pelaksanaan kegiatan berisi diskusi dan pelatihan alih media kaba menjadi carita anak dan komik. Oleh karenanya, kegiatan ini dilaksanakan dalam dua bagian, ceramah dan diskusi serta pelatihan singkat.

Berdasarkan pengamatan terhadap kegiatan ini, diperoleh simpulan kurangnya materi dan bahan ajar muatan lokal yang lebih menarik dan diterima oleh siswa didik untuk peningkatan pengetahuan mereka terhadap muatan lokal keminangkabauan, masih terbatasnya sarana guna pengembangan bahan ajar muatan keminangkabauan, penguasaan materi keminangkabauan yang tinggi tidak diimbangi dengan kreativitas pengolahannya menjadi bahan ajar yang lebih baik.
\end{abstract}

Kata kunci: sosialisasi, pelatihan, kaba, Minangkabau, cerita, komik.

\section{LATAR BELAKANG}

Salah satu bentuk karya seni sastra Minangkabau adalah kaba. Menurut Navis (1984), jika dilihat dari gaya bahasanya kaba betul-betul merupakan produk khas Minangkabau. Jika dilihat dari segi ceritanya, kaba dapat digolongkan menjadi dua, kaba klasik dan yang baru. Hal ini sejalan dengan Junus (1984) yang juga membagi dua kelompok kaba, kaba klasik dan tak-klasik.

Sebagai cerita, kaba terbentuk dan dibangun oleh beberapa unsur cerita. Secara umum, sebuah cerita (prosa) mengandung unsur tema, tokoh dan penokohan, alur cerita, dan latar cerita. Amanat dan pesan yang ada dalam cerita dibentuk dan dibangun melalui unsurunsur tersebut. Djamaris (2002) juga menambahkan bahwa kaba berfungsi sebagai hiburan, pelipur lara, dan sebagai nasihat. Di dalam kaba juga terkandung banyak nilai budaya.

Namun, dewasa ini, pengetahuan akan hasil seni tradisi, khususnya 
Minangkabau, tampak semakin terkikis dan berkurang. Masyarakat adat Minangkabau sendiri mulai merasa gelisah akan keadaan ini. Sepanjang pengetahuan pengusul, sebagian besar anak muda Minangkabau generasi yang lahir tahun 1980-an tidak mengenal hasil seni tradisinya. Mereka tidak lagi mengenal kaba, randai, indang, dan bahkan pasambahan.

Pengetahuan generasi muda dewasa ini terhadap hasil seni budaya tradisi tampak sangat kurang. Berdasarkan pengalaman pengusul mengajar di Fakultas Ilmu Budaya Universitas Andalas dan beberapa perguruan tinggi swasta di Padang, hanya sedikit siswa yang mengetahui dan mengenal hasil karya seni tradisi Minangkabau. Sangat ironis, bahwasanya mereka menuntut ilmu di Fakutas Ilmu Budaya, tetapi tidak mengenal karya seni dan budaya Minangkabau. 
Sementara itu, hasil kegiatan pengabdian kepada masyarakat yang telah dilaksanakan pengusul pada tahun 2008 menunjukkan masih terdapat potensi ketertarikan anak dan generasi muda terhadap karya seni tradisi Minangkabau. Dalam kegiatan tersebut, tim mengolah bentuk bahan ajar mata pelajaran Budaya Alam Minangkabau dalam bentuk gambar dan multimedia. Hasil kegiatan tersebut menunjukkan bahwa kemasan seni tradisi perlu disesuaikan dengan perkembangan teknologi, informasi, dan minat siswa sehingga siswa merasa lebih dekat dengan dunianya.

Dalam upaya mengenalkan dan melestarikan karya seni budaya tradisi kaba, perlu adanya sebuah bentuk transformasi kaba tersebut. Salah satu bentuk transfromasi itu adalah perubahan menjadi bentuk komik sehingga diharapkan akan lebih mudah diterima oleh khalayak penikmat terutama remaja dan anak-anak.

Komik di Indonesia pertama kali muncul pada tahun 1930-an dalam bentuk strip. Komik ini terdapat dalam sebuah media massa milik pemerintah Belanda De Java Bode dan D'orient. Hingga tahun 1960-an, komik di Indonesia berkembang masih dalam bentuk strip.

Masyarakat Indonesia pada umumnya menganggap komik adalah salah satu bentuk karya seni (sastra) yang kurang bermanfaat. Komik hanya dianggap sebagai cerita bergambar yang tidak memancing imajinasi pembacanya. Hal ini tentunya jika dibandingkan dengan genre karya sastra lainnya. Maya Mannes (dalam Heer, 2004) bahkan menyebutkan “Every hour spent in reading comics is an hour in which all inner growth has stopped". Dalam hal ini, Mannes mempertimbangkan kentalnya unsur kekerasan dalam komik. Sementara itu, di Indonesia, komik dianggap sebagai penyebab menurunnya moral. Mustaqim (2007) menyebutkan anggapan ini muncul 
dan berkembang setelah revolusi tahun 1965 dan pergantian politik dan kekuasaan di Indonesia.

Namun demikian, di sisi lain komik juga bisa dianggap sebagai salah satu bentuk bahan ajar yang paling mudah diterima oleh anak didik. Anak didik akan lebih mudah menerima dan memahami materi dan muatan-muatan yang terdapat dalam komik. Tidak sedikit komik yang mengandung muatan positif yang pada akhirnya tertanam pada anak didik. Tidak mengherankan apabila anak didik akan lebih memilih membaca komik daripada buku teks. Bahkan, beberapa buku teks pengantar bidang ilmu telah ditransformasi menjadi bentuk komik.

Pada tahun 1993, Fakultas Sastra Universitas Indonesia membentuk sebuah lembaga Kajian Komik Indonesia (KKI). Bahkan, sejak tahun 1998, Kementerian Departemen Pendidikan Nasional dan Kebudayaan bekerja sama dengan Balai Pustaka menyelenggarakan secara rutin sebuah kompetisi komik dan Comic and Animation Exhibition. Sejak tahun 1990-an, perkembangan komik Indonesia yang sempat mengalami kemunduran kembali memperlihatkan kemajuan. Hasilnya, hingga saat ini telah banyak komik-komik yang dibuat oleh anak-anak bangsa ini untuk berbagai kepentingan termasuk pendidikan.

Berdasarkan uraian di atas, dirasa sangat perlu sebuah bentuk karya seni bermuatan tradisi Minangkabau yang lebih berterima di khalayak penikmat muda. Dengan demikian, tidak hanya bentuk seni tersebut yang bisa diterima khalayak penikmat, tetapi juga aspek isi dan muatan budaya tradisi yang terkandung di dalamnya. Di samping itu, terdapat pertimbangan karya tradisi tersebut bisa dikenal tidak hanya oleh masyarakat Minangkabau. Di sisi lain, terdapat pula kemungkinan 
bentuk tersebut menjadi model atau acuan transformasi karya seni tradisi di luar Minangkabau sebagai bentuk upaya pengenalan dan pelestariannya.

Berdasarkan latar belakang di atas, maka tujuan program pengabdian kepada masyarakat ini bertujuan untuk mengadakan sosialisasi alih media kaba dalam ceramah dan diskusi.

\section{METODE KEGIATAN}

Kegiatan ini dilaksanakan dengan tahap-tahap berikut ini.

a. Persiapan

Persiapan ini mencakup konsulidasi tim dan persiapan-persiapan dalam hal surat menyurat.

b. Ceramah dan diskusi tentang alih media kaba. Tahap ini tim menunjuk narasumber yang mempresentasikan alih media kaba yang dilakukan dalam 2 (dua) sesi pertemuan.

\section{PELAKSANAAN DAN HASIL}

\subsection{KEGIATAN Persiapan}

Persiapan diawali diskusi tim untuk menentukan tugas masing-masing anggota tim. Di samping itu, diskusi juga menentukan waktu pelaksanaan kegiatan ini.

Dalam diskusi ini juga merancng pokok-pokok materi yang akan disampaikan dalam kegiatan. Pokok materi tersebut adalah transformasi cerita kaba menjadi cerita anak dan komik. Oleh karena materi tersebut adalah hasil penelitian anggota tim kegiatan ini, maka ditentukan narasumber adalah anggota tim sendiri. 
Peserta yang menjadi sasaran kegiatan ini adalah guru-guru mata pelajaran muatan lokal di Padang. Oleh karenanya, undangan ditujukan pada guru-guru muatan lokal tingat SMP se-Kota Padang.

\subsection{Pelaksanaan}

Kegiatan ini dilaksanakan dalam waktu dua hari, yaitu pada 14 dan 15 Oktober 2014 bertempt di Ruang Sidang Jurusan Sastra Daerah Universitas Andalas. Hari pertama kegiatan ini berisi ceramah dari narasumber dan diskusi antara narasumber dan peserta. Adapun peserta yang disasar dalam kegiatan ini adalah guru-guru mata pelajaran muatan lokal se-kota Padang. Namun, oleh karena beberapa hal, tidak semua peserta undangan hadir dalam kegiatan ini. Kegiatan ini dihadiri oleh 32 orang peserta.

Materi ceramah dan diskusi pada pelaksanaan kegiatan hari pertama adalah beberapa kemungkinan transformasi karya sastra Minangkabau, khususnya cerita kaba. Narasumber memberikan kemungkinan transformasi kaba menjadi cerita anak dan komik. Hal ini disesuaikan dengan pengolahan bahan ajar muatan lokal keminangkabauan yang diampu oleh peserta.

Dalam diskusi hari pertama ini, peserta sangat antusias untuk turut mengembangkan cerita-cerita lokal. Peserta akhirnya mengembangkan sumber transformasi tersebut bukan hanya dari cerita melainkan juga dari cerita-cerita rakyat Minangkabau yang tersebar di wilayah Sumatera Barat.

Hari kedua diisi materi pelatihan transformasi cerita menjadi cerita anak dan komik. Kegiatan hari kedua ini bisa dikatakan kurang maksimal karena waktu yang terbatas. Materi hari kedua ini adalah memberikan latihan kepada peserta untuk 
memgubah dan membentuk cerita rakyat menjadi cerita anak dan komik. Berdasarkan materi yang telah diberikan pada hari pertama, peserta sangat menikmati diskusi yang dilaksanakan. Dalam pelaksanaannya, peseta dibagi menjadi beberapa kelompok. Masing-masing kelompok yang terdiri atas 3-5 orang mengolah satu judul cerita. Kreativitas peserta sangat dibutuhkan dalam hal ini. Peserta dibimbing untuk mengolah cerita menjadi lebih ringan. Pengolahan tersebut mulai dari pengolahan alur cerita, penokohan, hingga gaya bahasa yang lebih bisa diterima oleh anak didik. Meskipun peserta tidak bisa menghasilkan cerita utuh, tetapi boleh dikatakan hasilnya sangat memuaskan.

\subsection{Hasil dan Analisis}

Seperti telah disampaikan di atas, hasil kegiatan ini secara umum bisa dikatakan berhasil. Jumlah peserta yang mengikuti kegitan ini adalah salah satu indikatornya. Di samping itu, semangat peserta mengikuti setiap materi dan diskusi juga tinggi. Bahkan beberapa peserta meminta untuk diadakan kembali kegiatan serupa.

Kegiatan pengabdian ini adalah wujud kelanjutan hasil penelitian yang dilakukan oleh anggota tim. Baik penelitian dan pengabdian ini dilatarbelakangi semakin berkurangnya pengetahuan siswa sekolah tentang muatan cerita-cerita kaba. Oleh karenanya, tim berusaha untuk melakukan sosialisasi hasil penelitian kepada guru-guru sebagai bekal dan bahan pembelajaran di kelas.

Tuntutan terhadap kreativitas yang tinggi ternyata bukan halangan untuk menciptakan karya yang lebih menarik. Hal ini dibuktikan dalam kegiatan ini. 
Dengan berkelompok, ide dan krativitas bisa digabung menjadi sebuah karya yang baik.

Dalam kesempatan tersebut juga disampiakan kemungkinan penerbitan karyakarya guru yang layak. Hal ini diharapkan bisa tetap mempertahankan semangat peserta kegiatan untuk tetap berkarya.

\section{PENUTUP}

Berdasarkan pengamatan terhadap kegiatan ini, diperoleh simpulan sebagai berikut.

a. Kurangnya materi dan bahan ajar muatan lokal yang lebih manarik dan diterima oleh siswa didik untuk peningkatan pengetahuan mereka terhadap muatan lokal keminangkabauan.

b. Masih terbatasnya sarana guna pengembangan bahan ajar muatan lokal keminangkabauan.

c. Penguasaan materi keminangkabauan yang tinggi tidak diimbangi dengan kreativitas pengolahannya menjadi bahan ajar yang lebih baik.

Di samping itu, beberapa saran terkait dengan kegiatan ini dpat disampaikan sebagai berikut.

a. Sangat penting untuk mempertahankan muatan lokal sebagai salah satu mata pelajaran yang diberikan di tingkat sekolah dasar dan menengah.

b. Perluasan kesempatan kreativitas guru untuk mengembangkan materi dan bahan ajar. 

c. Peningkatan baik kualitas maupun kuantitas sarana penunjang proses pembelajaran muatan lokal keminangkabauan.

\section{DAFTAR PUSTAKA}

Navis, A.A. 1984. Alam Takambang Jadi Guru: Adat dan Kebudayaan Minangkabau. Jakarta: Grafiti Pers.

Junus, Umar. Kaba dan Sistem Sosial Minangkabau: Suatu Problema Sosiologi Sastra. Jakarta: Balai Pustaka.

Djamaris, Edwar. 2002. Pengantar Sastra Rakyat Minangkabau. Jakarta: Yayasan Obor Indonesia.

Heer, Jeet dan Kent Worcester (ed). 2004.Arguing Comics: Literary Masters on Popular Medium. Mississippi: University Press of Mississippi.

Mustaqim, Karna. 2007. Mumbling Our Comics: An Overview of Indonesian Comic Book's Condition. dalam International Journal Comic Arts 9 No 1 Spring 2007 halaman 331-331.

McCloud, Scott. 1993. Understanding Comics: The Invisible Art. New York: Kitchen Sink Press. 